\title{
Toxicants Formed in Fires of Captafol Pesticide
}

\author{
KAI CHEN ${ }^{1}$, DOMINIKA A. WOJTALEWICZ ${ }^{1}$, JOHN C. MACKIE ${ }^{1,2}$, ERIC M. KENNEDY ${ }^{1}$, and \\ BOGDAN Z. DLUGOGORSKI ${ }^{1}$ \\ ${ }^{1}$ Priority Research Centre for Energy \\ Faculty of Engineering and Built Environment \\ The University of Newcastle, Callaghan, New South Wales 2308, Australia \\ ${ }^{2}$ School of Chemistry \\ The University of Sydney \\ New South Wales 2006, Australia
}

\begin{abstract}
This study presents an investigation into the gas phase thermal decomposition of captafol, a sulfenimide fungicide which consists of a thiotetrachloroethyl $\left(-\mathrm{SCCl}_{2} \mathrm{CHCl}_{2}\right)$ group bonded to a tetrahydrophthalimide $\left(\mathrm{C}_{6} \mathrm{H}_{8}(\mathrm{CO})_{2} \mathrm{~N}-\right)$ moiety. The experiments were performed on a bench type apparatus, under conditions representing both under and well-ventilated non-flaming fires. The analyses of gaseous species relied on Fourier transform infra-red spectroscopy (FTIR) and micro gas chromatography ( $\mu \mathrm{GC})$, resulting in the identification and quantification of 11 gaseous products; among them, phosgene, thiophosgene and hydrogen cyanide. Gas chromatography - quadrupole mass spectrometry (GC-QMS) was employed to analyse the condensed products and volatile organic compounds (VOC), while a GC equipped with an ion trap mass spectrometer (GC-ITMS) was used to quantify polychlorinated dibenzo- $p$-dioxins and dibenzofurans (PCDD/F). The GC-QMS analysis determined several VOC toxicants; viz., trichloroethylene, tetrachloroethylene, benzonitrile and chlorinated benzenes. At higher temperature $\left(600{ }^{\circ} \mathrm{C}\right)$, the oxidation of captafol led to the formation of mono- to hepta- $\mathrm{CDD} / \mathrm{F}$ congeners including the most toxic 2,3,7,8-TCDD. In addition, the experimental results were compared to those of the other two sulfenimide fungicides, captan and folpet, both of which contain the thiotrichloromethyl $\left(-\mathrm{SCCl}_{3}\right)$ moiety rather than the thiotetrachloroethyl group of captafol. It appears that the thiotetrachloroethyl group in captafol is responsible for the difference in the toxic pollutants formed, particularly influencing the distribution and yields of PCDD/F congeners. Combined with quantum chemical calculations, the results presented in this article provide an insightful understanding of fire chemistry of the sulfenimide fungicides, especially the pathways to the formation of major toxicants during the oxidative thermal decomposition of captafol.
\end{abstract}

KEYWORDS: captafol, air pollutants, PCDD/F, toxicity.

\section{INTRODUCTION}

Captafol (IUPAC name of 2-(1,1,2,2-tetrachloroethylsulfanyl)-3a,4,7,7a-tetrahydroisoindole-1,3-dione) is a member of the sulfenimide group of fungicides which also includes captan and folpet. Introduced in 1961 by Chevron, it has been employed as a protective non-systemic fungicide to control foliage and fungicaused diseases in a number of vegetable and fruit crops [1]. Captafol has also been utilised in the timber industry as preservatives for wood products [2]. Owing to the carcinogenic effect of captafol on humans, many countries have withdrawn its use from markets since the late 1980s [3]. However, the application of captafol in agriculture continues in some regions [4,5]. As pesticides decompose to toxic products during the combustion process, accidental fires of pesticides in storage and transport attract considerable media and regulatory attention [6,7]. Furthermore, in bush, wildland, forest and agricultural fires, the uncontrolled burning of biomass contaminated with pesticides generates toxic mixtures of smoke and gases, imposing significant toxic load on the surrounding environment [8,9]. Under fire conditions, emissions from smouldering or thermal damage events, where the stored pesticide is exposed to heat from flames, may force the pesticide to decompose thermally to more toxic fragments of the original molecule and the corresponding oxides.

Owing to the widespread applications of sulfenimide fungicides in agriculture and industry, in the latter as feedstocks for chemical synthesis, our group has previously studied the formation of toxic air pollutants and PCDD/F in oxidation of captan and folpet [10-12]. These two fungicides exhibit similar chemical structures, with the characteristic thiotrichloromethyl group bonded to tetrahydrophthalimide (THPI) 
moiety in captan and phthalimide (PI) in folpet, respectively (Fig. 1). Although both pesticides produce similar toxicants, we discovered that the availability of abstractable hydrogen in their structures defines the yields of toxic species [13]. In comparison with captan and folpet, captafol comprises the thiotetrachloroethyl, rather than thiotrichloromethyl, moiety, as illustrated in Fig. 1. From this perspective, the present study aims to gain insights into the formation of toxicants in fires of captafol, especially into the effect of the thiotetrachloroethyl group present in its structure.

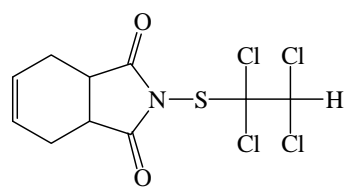

captafol

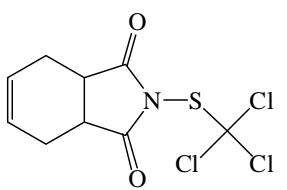

captan<smiles>O=C1c2ccccc2C(=O)N1SC(Cl)(Cl)Cl</smiles>

folpet<smiles>O=C1NC(=O)C2CCCCC12</smiles>

THPI

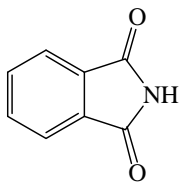

PI

Fig. 1. Chemical structures of captafol, captan, folpet, tetrahydrophthalimide (THPI) and phthalimide (PI).

Studies of the thermal decomposition of captafol under oxidative conditions have rarely been documented. Klusmeier et al. investigated the combustion products of captafol by collecting HCN in a solvent scrubber while trapping the organic compounds in activated charcoal and XAD-4 resin cartridges [14]. The GC-MS measurements revealed several volatile and condensed organic products including phthalimide and trichloroethylene, affording formulation of a preliminary mechanism of fire chemistry of captafol. However, the detailed thermal decomposition pathways of captafol have not been established owing to the lack of complete analysis of all gaseous products. Prior to the present study, no attempts have been undertaken to determine the emission of PCDD/F from captafol fungicide.

This article reports results from a detailed study of gas phase, non-flaming thermal decomposition of captafol in both oxygen lean and oxygen rich atmosphere, to determine the formation of toxic products, and to gain insights into the fire chemistry of this pesticide. We have studied the effect of both oxygen-lean and oxygen-rich environments with equivalence ratio of $\varphi>1$ and $\varphi<1$, respectively, by controlling the oxygen level, denoted hereafter as low oxygen pyrolysis (LOP) and oxidation (OXD), respectively. A temperature range of $400-500{ }^{\circ} \mathrm{C}$ was selected for the LOP studies and $400-600{ }^{\circ} \mathrm{C}$ for the OXD experiments, as ISO 19706 classifies that maximum temperatures of pyrolysis and oxidative non-flaming fires correspond to 500 and $600{ }^{\circ} \mathrm{C}$, respectively [15]. DFT (density functional theory) calculations assisted the interpretation of experimental results. Together with our previous investigations of captan and folpet, the results reported in this contribution provide a comprehensive assessment of the chemical behaviour of sulfenimide fungicides in non-flaming fires. The experimental measurements of a large variety of toxic products, including gases, VOC and PCDD/F, will enable the assessments of fire toxicity of captafol.

\section{EXPERIMENTAL}

\section{Reactor System}

Similarly to the equipment deployed in our previous studies on captan and folpet, the bench-scale apparatus consists of three major components, a pesticide vaporiser, an isothermal alumina tubular reactor and a collection system for different types of products (Fig. 2). The gaseous species flow through a desiccant tube (loaded with drierite) into a tedlar air-sampling bag (SKC, USA). We captured the VOC products, in separate experiments, by an adsorbent cartridge packed with $100 \mathrm{mg}$ of activated charcoal (Merck, Australia) while two XAD-2 resin cartridges in tandem functioned as a trap for PCDD/F. At the downstream end of the sampling line, the exhaust gases were directed through a solvent trap containing a mixture of dichloromethane (Merck, Australia) and methanol (Sigma-Aldrich, Australia), chilled in a cold glycol bath $\left(0^{\circ} \mathrm{C}\right)$.

For the oxidation experiments, captafol (PESTANAL ${ }^{\circledR}$ ) powder, purchased from Sigma-Aldrich, Australia, was loaded onto a tray positioned in a polytetrafluoroethylene (PTFE) tube installed vertically inside the vaporiser, with the vaporiser placed in an GC oven (Shimadzu, Japan) maintained at $165{ }^{\circ} \mathrm{C}$ to slowly generate pesticide vapour (approximately $0.045 \mathrm{mg} / \mathrm{min}$ ), equivalent to a concentration of approximately $0.18 \%(\mathrm{w} / \mathrm{w})$. Owing to the heavier molecular weight (MW) of captafol, the operation temperature of the 
vaporiser was set to $15{ }^{\circ} \mathrm{C}$ higher than that used to evaporate the comparable amounts of captan and folpet. Given such a small evaporation rate, we employed $280 \pm 30 \mathrm{ppm} \mathrm{O}_{2}$ in $\mathrm{N}_{2}$ (v/v) for the LOP conditions and $6.0 \pm 0.5 \% \mathrm{O}_{2}$ in $\mathrm{N}_{2}(\mathrm{v} / \mathrm{v})$ for OXD, which results in the fuel equivalence ratios $(\varphi)$ in the LOP and OXD experiments of 6.9 and 0.03 respectively.

Pure nitrogen (99.999\%) continuously flowed through the vaporiser tube and swept the diluted vapour towards the reactor. A controlled amount of pure oxygen (99.999\%) was introduced into the reactant flow, with the concentration of $\mathrm{O}_{2}$ monitored online by a Varian CP 2003 micro gas chromatograph (Varian, Australia). The thermal decomposition of captafol occurred in the central (reactor) zone of a high temperature alumina tube (99.8\%) insulated at both ends and maintained at isothermal conditions by a three-zone electrically heated furnace, operated at $400-600{ }^{\circ} \mathrm{C}$. A transfer line $\left(180^{\circ} \mathrm{C}\right)$ coupled the reactor to the adjacent vaporiser, with two alumina rods inserted into the both ends of reactor tube to maintain the same residence time of $1 \mathrm{~s}$ in all experiments except during sampling of PCDD/F, where the residence time was increased to $5 \mathrm{~s}$.

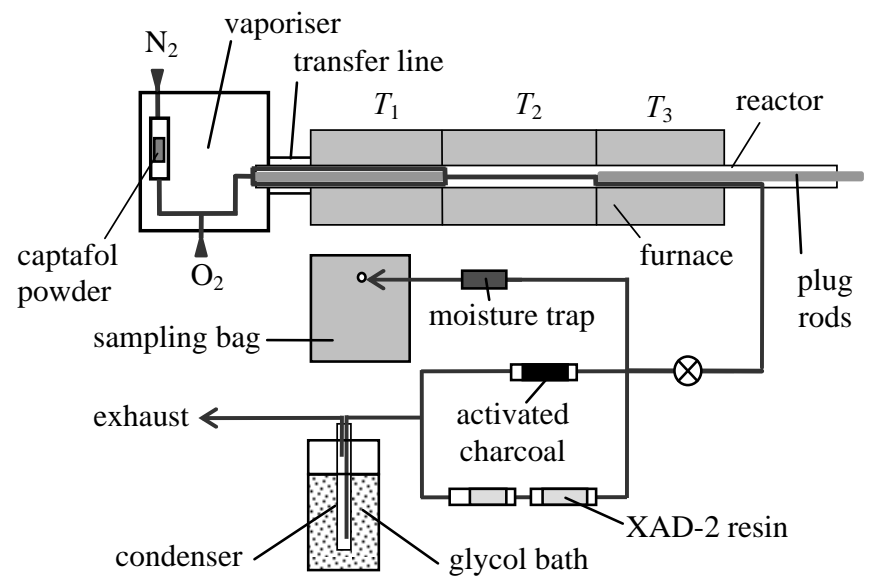

Fig. 2. A schematic diagram of the experimental set-up.

\section{Product Analysis}

With the details of similar analytical procedure for captan and folpet described in our previous studies $[10,11]$, here, we only provide a brief description. The gaseous species collected in the sampling bag were initially transferred into the pre-evacuated gas cell (10 m IR path) mounted on a Varian 660-IR spectrometer (Varian, Australia). Subsequently, the gas cell was topped up to the atmospheric pressure by feeding in pure nitrogen (99.999\%). Each sample was scanned 32 times over the range of $4000-500 \mathrm{~cm}^{-1}$ at a resolution of $0.5 \mathrm{~cm}^{-1}$. The identification and quantification of gaseous products, except for $\mathrm{CO}_{2}$, relied on the QASoft software package (Infrared Analysis, USA). On account of the intense FTIR response of $\mathrm{CO}_{2}$ exceeding the linearity region [16], a $\mu \mathrm{GC}$ calibrated with gas standards served to determine the $\mathrm{CO}_{2}$ concentration.

The activated charcoal was extracted with $1 \mathrm{~mL}$ of carbon disulfide $\left(\mathrm{CS}_{2}\right)$, following the procedure in the National Institute for Occupational Safety and Health (NIOSH) Method 1003. The extracted solution containing VOC species required filtration prior to injection into GC, not to block the syringe or the GC capillary column and avoid contaminating the injector with carbon particles. The condensed products were dissolved in $\mathrm{CS}_{2}$ and combined with the solution from the solvent trap for subsequent GC-QMS analysis. The mixtures of VOC (or condensed products) were separated on a $30 \mathrm{~m}$ Varian VF-5ms capillary column ( $0.25 \mathrm{~mm}$ diameter $\times 0.25 \mu \mathrm{m}$ film thickness) housed in a Varian CP3800 gas chromatograph. The GC was coupled to a Varian 1200 quadrupole mass spectrometer, with detailed parameters of GC-QMS operation similar to those implemented in our previous studies $[10,11]$, except for the GC oven program adopted to analyse the condensed products. The initial column temperature was held at $60{ }^{\circ} \mathrm{C}$ for $5 \mathrm{~min}$ and subsequently ramped up to $180^{\circ} \mathrm{C}$ (held for $1 \mathrm{~min}$ ) at a rate of $10^{\circ} \mathrm{C} \cdot \mathrm{min}^{-1}$, then increased to $280{ }^{\circ} \mathrm{C}$ (held for $3 \mathrm{~min}$ ) at $20^{\circ} \mathrm{C} \cdot \mathrm{min}^{-1}$. In addition to identifying eluted peaks by matching their mass spectra with those 
from the NIST library, we prepared solutions of authentic standards to confirm the retention times and quantify the amounts produced.

For the trace analysis of PCDD/F, the XAD-2 resin was Soxhlet (Buchi, Switzerland) extracted with hot toluene for $5 \mathrm{~h}$. The extract and DCM solvent from washing the reactor tube and other sampling parts were concentrated separately and followed by clean-up on glass chromatography columns loaded with acid and basic alumina (3 g each). The chemical interferences were eluted with $15 \mathrm{~mL}$ hexane and then $30 \mathrm{~mL}$ DCM/hexane $(2: 98 \mathrm{v} / \mathrm{v})$. We collected the third fraction, $50 \mathrm{~mL}$ of DCM/hexane $(1: 1 \mathrm{v} / \mathrm{v})$, for further concentration in a rotary evaporator, and then under gentle nitrogen flow, to a final volume of $20 \mu \mathrm{L}$ in $n$ decane. The quantifications of PCDD/F congeners were performed on a Varian CP3800 GC equipped with a Varian Saturn 2000 ion trap MS.

\section{Computational Details}

All structures have been optimised using the DFT functional of B3LYP [17] together with the basis set of 6-31G(d). Single point energies were performed on the optimised structures at the B3LYP/6$311+G(3 d f, 2 p)$ level. Transition structures (TS) on potential energy surfaces (PES) have been characterised as first-order saddle points by possessing one and only one imaginary frequency. Transition structures were confirmed by connecting the related reactants and products by intrinsic reaction coordinate (IRC) analysis. All optimisations have been performed using the Gaussian (G03) suite of programs.

\section{RESULTS AND DISCUSSION}

The interpretation of FTIR spectra identified 11 species, including phosgene $\left(\mathrm{COCl}_{2}\right)$, thiophosgene $\left(\mathrm{SCCl}_{2}\right)$, trichloroethylene $\left(\mathrm{C}_{2} \mathrm{HCl}_{3}\right)$, hydrogen chloride $(\mathrm{HCl})$, carbon disulfide $\left(\mathrm{CS}_{2}\right)$, carbonyl sulfide (COS), sulfur dioxide $\left(\mathrm{SO}_{2}\right)$, benzene $\left(\mathrm{C}_{6} \mathrm{H}_{6}\right)$, hydrogen cyanide $(\mathrm{HCN})$ and carbon oxides $\left(\mathrm{CO}\right.$ and $\left.\mathrm{CO}_{2}\right)$. Most of these chemicals cause negative health effects [18-21]. Figure 3a illustrates the typical FTIR spectra, with the water vapour interferences removed, for gases captured from the experiments performed at $400{ }^{\circ} \mathrm{C}$ under both the OXD and LOP conditions. In addition to the 9 marked species, the distinctive $Q$ branch of benzene and HCN can be observed at 674 and $712 \mathrm{~cm}^{-1}$, respectively.

Owing to the overlapping spectra of different gases, the identification of some species requires spectral subtraction. For instance, the unique absorption of $\operatorname{SCCl}_{2}\left(1200-1100 \mathrm{~cm}^{-1}\right)$ can be unveiled through the subtraction of the $\mathrm{SO}_{2}$ spectrum. The absorption of $\mathrm{C}=\mathrm{O}$ stretch $\left(1832\right.$ and $\left.1820 \mathrm{~cm}^{-1}\right)$ most likely arises from phosgene which should also exhibit absorption due to $\mathrm{C}-\mathrm{Cl}$ bend at 856 and $848 \mathrm{~cm}^{-1}$; the latter masked by the presence of trichloroethylene and thiophosgene. To confirm the detection of $\mathrm{COCl}_{2}$, we subtracted the spectra of $\mathrm{C}_{2} \mathrm{HCl}_{3}$ and $\mathrm{SCCl}_{2}$ and the resulting spectrum matches well with the reference spectrum of phosgene (Fig. 3b).

Emission factors (EF) of all gaseous products ( $\mathrm{mg} \mathrm{g}^{-1}$ captafol) under different experimental conditions was determined (Table 1). The results from the FTIR analyses of products of repeated experiments provided reasonably reproducible results ( $< \pm 15 \%)$, except for trichloroethylene. Owing to its relatively high boiling point of $87.2{ }^{\circ} \mathrm{C}$ [22], we believe that the condensation of trichloroethylene in the gas cell (room temperature) explains the erroneous results. Thus, the quantification of trichloroethylene was achieved by GC-QMS. Hydrogen chloride shows a higher EF under the OXD conditions compared to those of LOP conditions, with its formation promoted at elevated temperature. The emission of phosgene and thiophosgene only occurs at $400{ }^{\circ} \mathrm{C}$ in the OXD experiments. The EF of carbon disulfide declines with increasing temperatures under the OXD conditions, with a significant emission observed at $500{ }^{\circ} \mathrm{C}$ in the oxygen-lean atmosphere. The remaining gaseous species show increasing yields as the $\mathrm{O}_{2}$ concentration in the carrier gases increases from $280 \mathrm{ppmv}$ to $6.0 \%$. Most of these species attain their maximal EF at the highest temperatures investigated, except for carbonyl sulfide (OXD) and sulfur dioxide (LOP). In the oxygen rich atmosphere, toxic gases mainly form under relatively low temperatures $\left(<600{ }^{\circ} \mathrm{C}\right)$, as captafol oxidises to the corresponding oxides of carbon, sulfur and nitrogen at higher temperatures.

Figure 4a illustrates the chromatograms of VOC analyses obtained from the experiments carried out at $500{ }^{\circ} \mathrm{C}$ under both the LOP and OXD conditions. The identified compounds include trichloroethylene (TriCE), tetrachloroethylene (TCE), chlorobenzene (CB), benzonitrile (BZN), dichlorobenzene (DCB) and 
chlorobenzonitrile (CBN). Among three isomers of DCB, 1,2-dichlorobenzene was identified as the most abundant.

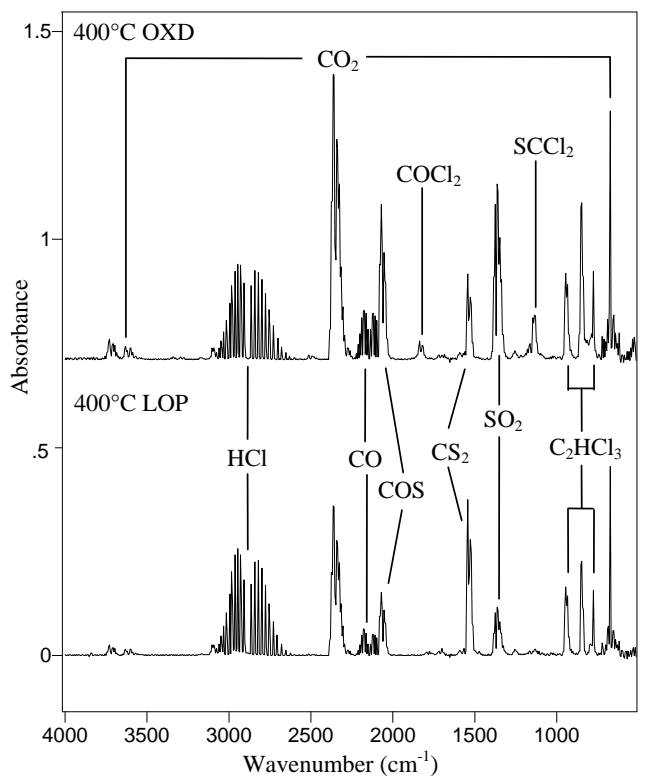

(a)

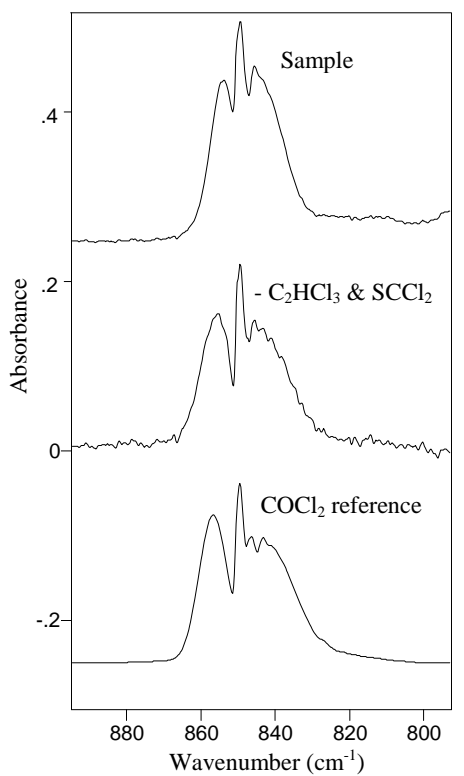

(b)

Fig. 3. (a) FTIR spectra of gases products from experiments conducted at $400{ }^{\circ} \mathrm{C}$ under both the $\mathrm{OXD}$ and LOP conditions; (b) the confirmation of $\mathrm{COCl}_{2}$ peak through subtraction of reference spectra.

Table 1. Emission factors of gaseous species under the LOP and OXD conditions.

\begin{tabular}{|c|c|c|c|c|c|}
\hline \multirow{3}{*}{ Product } & \multicolumn{5}{|c|}{ Emission Factor (mg g ${ }^{-1}$ captafol) } \\
\hline & \multicolumn{2}{|c|}{ LOP $\left(280 \mathrm{O}_{2} \mathrm{ppmv}\right)$} & \multicolumn{3}{|c|}{ OXD $\left(6.0 \% \mathrm{O}_{2} \mathrm{v} / \mathrm{v}\right)$} \\
\hline & $400{ }^{\circ} \mathrm{C}$ & $500^{\circ} \mathrm{C}$ & $400^{\circ} \mathrm{C}$ & $500{ }^{\circ} \mathrm{C}$ & $600^{\circ} \mathrm{C}$ \\
\hline $\mathrm{HCl}$ & 35.1 & 95.2 & 63.8 & 134 & 163 \\
\hline $\mathrm{COCl}_{2}$ & 0.0 & 0.0 & 9.6 & 0.0 & 0.0 \\
\hline $\mathrm{SCCl}_{2}$ & 0.0 & 0.0 & 15.5 & 0.0 & 0.0 \\
\hline $\mathrm{CS}_{2}$ & 19.8 & 37.7 & 9.4 & 7.4 & 4.8 \\
\hline cos & 7.0 & 13.1 & 15.3 & 24.4 & 21.8 \\
\hline $\mathrm{SO}_{2}$ & 27.3 & 19.4 & 93.7 & 133 & 136 \\
\hline $\mathrm{CO}$ & 19.3 & 32.5 & 49.5 & 73.2 & 82.2 \\
\hline $\mathrm{CO}_{2}$ & 36.9 & 120 & 143 & 354 & 422 \\
\hline $\mathrm{C}_{6} \mathrm{H}_{6}$ & 4.2 & 9.2 & 8.7 & 13.6 & 17.4 \\
\hline HCN & 2.3 & 3.9 & 2.6 & 6.0 & 9.0 \\
\hline
\end{tabular}

Our interest in the present study focuses on BZN, TriCE, TCE, CB and DCB. Benzonitrile has been documented to cause genotoxicity [23] while both TriCE and TCE are classified as suspect carcinogens [24]. Chlorinated benzenes have been identified as important precursors of PCDD/F [25]. We quantified these five toxic VOC species by multi-level external standard calibration, with their EF under different experimental conditions compared in Fig. 4b. The bottom panel shows the results of chlorinated benzenes whose emission factors are less than those of the other three products indicated in the upper part. Trichloroethylene is the most abundant VOC species detected in products of all experiments. Under the LOP conditions, captafol produced similar amounts of TriCE at both temperatures. With less TriCE formed in the OXD experiments, the yield of TriCE attains a maximum at $500{ }^{\circ} \mathrm{C}$, decreasing below and above this temperature. Tetrachloroethylene exhibits declining yields towards higher temperatures under the OXD conditions but an opposite trend emerges in the LOP results. Benzonitrile, an important product arising from the THPI moiety in captafol molecule, has its EF increasing with temperature, with the emission factors from the OXD experiments significantly higher than those of LOP measurements. The formation of chlorinated benzenes is promoted at the higher temperature and increasing oxygen concentration. Only detected under the OXD conditions, DCB shows a smaller yield than CB. 


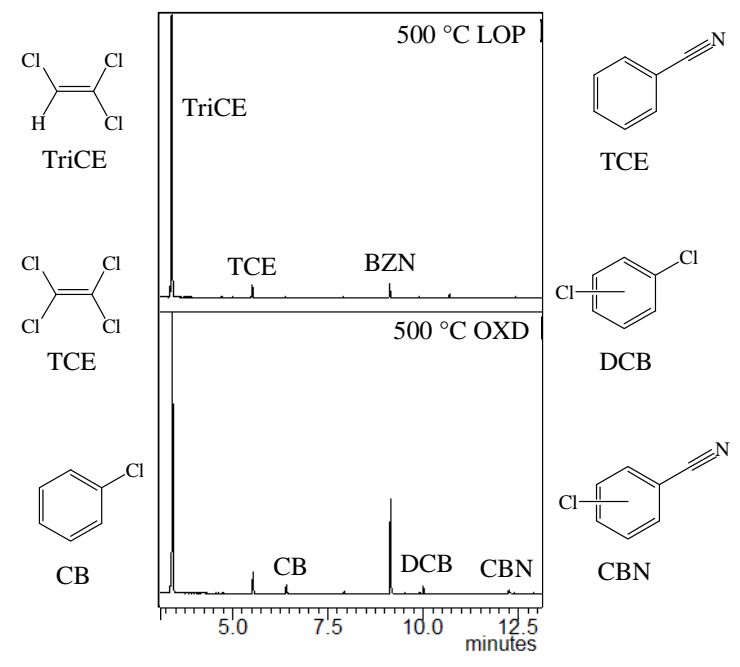

(a)

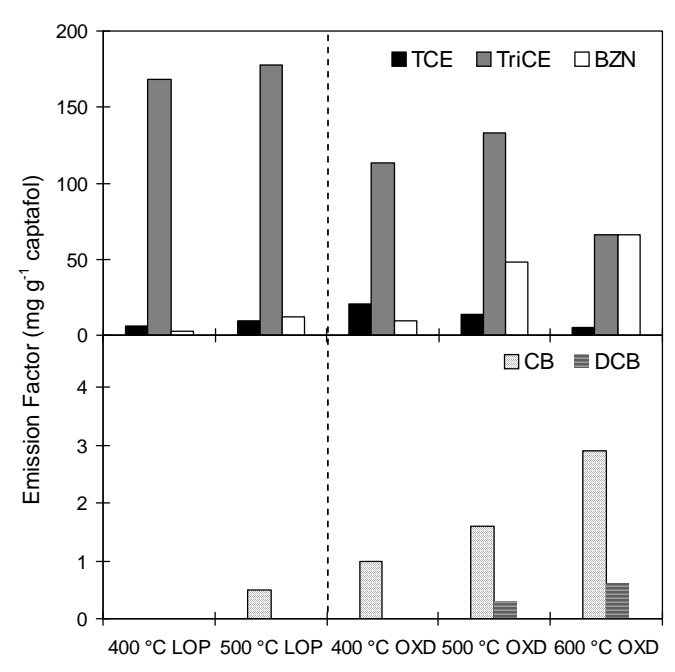

(b)

Fig. 4. (a) Chromatograms of VOC analyses at $500^{\circ} \mathrm{C}$; (b) yields of toxic species.

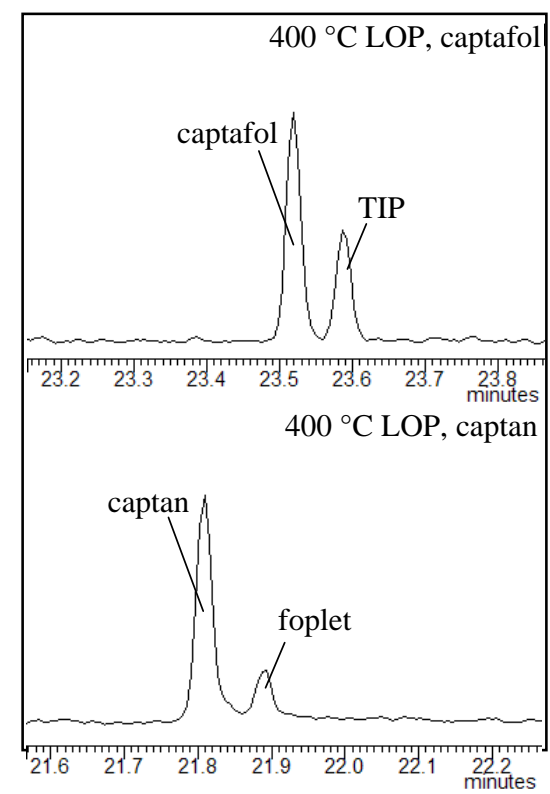

(a)

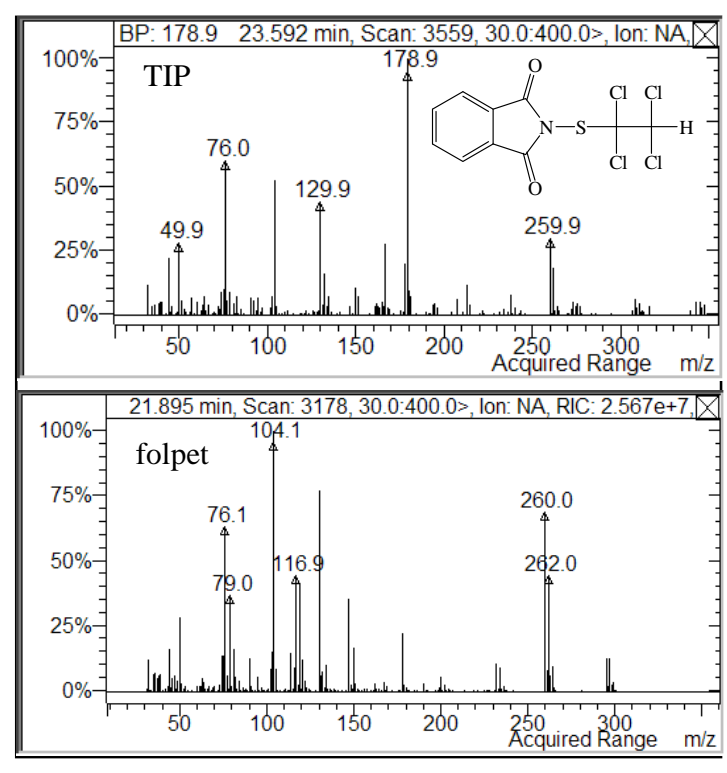

(b)

Fig. 5. Chromatogram and mass spectrum of tentative identified condensed product (TIP) in the captafol, compared to those of captan experiments [10].

Regarding the GC-QMS analyses of condensed products, comparison of spectra obtained from the NIST library with those of authentic standards has enabled us to identify confidently three compounds, including un-decomposed captafol (retention time of $23.5 \mathrm{~min}$, MW of 347), THPI (16.2 min, 151) and PI (15.9 min, 147). The chromatogram also indicated another peak eluted immediately after captafol at $23.6 \mathrm{~min}$, as indicated in the upper panel of Fig. 5a. The mass spectrum clearly shows that the compound (upper pane in Fig. 5b) has a MW of 343 even though the search in NIST library returned no structure identification. The analysis of isotope pattern of the spectrum indicated that the structure comprises four chlorine atoms. Thus, it appears that this compound is produced by the loss of four $\mathrm{H}$ from captafol. In our previous study of captan decomposition, we have discussed that abstraction of four $\mathrm{H}$ on the cyclohexene ring in the THPI moiety forms folpet, a fully aromatised compound [10]. The mass spectrum of folpet (lower pane in Fig. 5b) exhibits similar fragment ions with that of the unknown peak, particularly in the range $<200 \mathrm{~m} / \mathrm{z}$. Therefore, 
we tentatively identify this compound as the aromatised version of captafol, 2-[(1,1,2,2tetrachloroethyl)sulfanyl]-2,3-dihydro-1H-isoindole-1,3-dione (CAS: 2939-94-8), with its structure illustrated in Fig 5b. For the sake of abbreviation, this compound will be referred hereafter as tentatively identified compound (TIP). The bottom chromatogram in Fig. 5a demonstrates that the retention times of captan and folpet display a similar order to that of captafol and TIP. However, lack of a commercially available standard enabled no confirmation of the proposed species.

A multi-level standard calibration served to quantify the condensed species, with their EF under different conditions compared in Fig. 6. We assumed that the TIP exhibits the same response factor as captafol on the MS detector and calculated its approximate yield. Captafol achieved complete conversion under most conditions except for the LOP experiment at $400{ }^{\circ} \mathrm{C}$, in which a small amount of TIP was also detected. As the dominant product under the LOP conditions, THPI was only observed at $400{ }^{\circ} \mathrm{C}$ in the OXD study. The yields of THPI drop at elevated temperatures, accompanied by increasing yields of PI. In the OXD experiments, the emission factor of phthalimide reaches the highest value at $500{ }^{\circ} \mathrm{C}$ and then decreases as further oxidation occurs at $600{ }^{\circ} \mathrm{C}$.

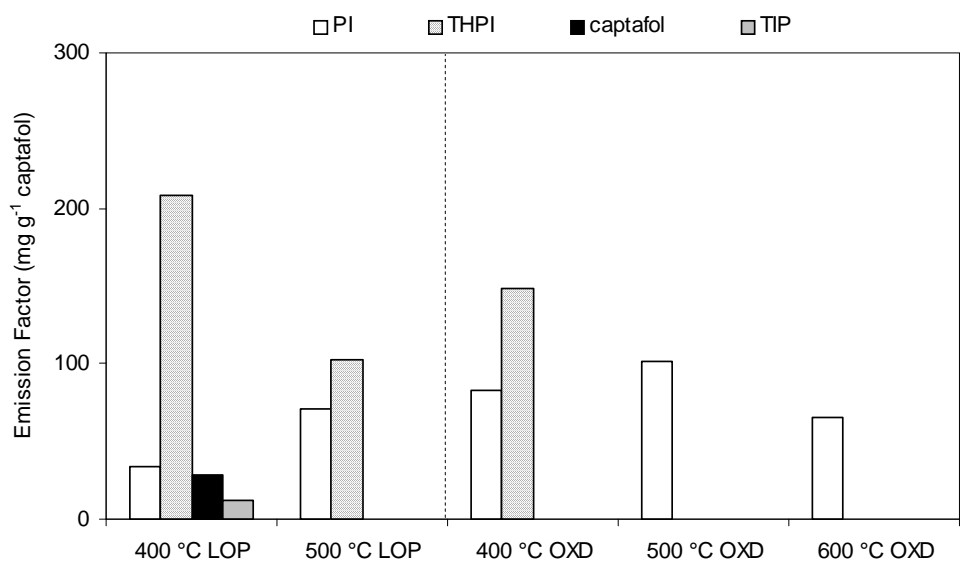

Fig. 6. Emission factors of condensed products from the combustion of captafol.

Generally, the results of captafol decomposition indicated satisfactory recoveries of sulfur and carbon (recoveries $>80 \%$ ) in the OXD experiments except for $\mathrm{S}$ at $400{ }^{\circ} \mathrm{C}$. Similarly to the experiments of captan and folpet, we observed a brownish yellow sulfur residue on the reactor tubes, responsible for the sulfur deficiency. Under the LOP conditions, the black residue indicated the formation of soot, which resulted in low recovery of carbon (70-75\%). The concomitant release of $\mathrm{H}$ attached on the cyclohexene ring of captafol may react with sulfur to form hydrogen sulfide gas $\left(\mathrm{H}_{2} \mathrm{~S}\right)$. The FTIR response of $\mathrm{H}_{2} \mathrm{~S}$ is extremely weak, which may explain the low sulfur recovery under such conditions. With the detailed reasons discussed elsewhere [10], the underestimation of $\mathrm{HCl}$ by FTIR led to chlorine deficiency in product species. The additional ion chromatographic (IC) analysis of $\mathrm{Cl}^{-}$, present in the solution $(\mathrm{NaOH})$ used to scrub the exhaust gases of acid species, helped to improve the chlorine recoveries. For instance, a reasonable chlorine balance of $86.9 \%$ was achieved by IC analysis for the OXD experiment performed at $500{ }^{\circ} \mathrm{C}$.

Consistent with our previous studies of captan and folpet, a residence time of $5 \mathrm{~s}$ was afforded for the separate OXD experiment at $600{ }^{\circ} \mathrm{C}$ to sample PCDD/F. The limits of quantification (LOQ) of our GCITMS instrument for PCDD/F standards correspond to between 0.6 and $9.9 \mathrm{pg}^{\mathrm{N}} \mathrm{L}^{-1}$ (except for octachlorinated dibenzofuran where the LOQ is $11.7 \mathrm{pg}^{-1} \mathrm{~L}^{-1}$ ). Table 2 lists the quantitative results of each PCDD/F homologue group condensing in the different parts of our sampling line. We detected a number of PCDD/F congeners with the chlorination content from mono to hepta. Overall, the results indicate that the oxidation favoured the gas phase formation of PCDF in comparison with that of PCDD (6:1 w/w). The majority of PCDD/F congeners were observed condensing on both reactor and PTFE join tubes, the trend increasing with degree of chlorination. No breakthrough of PCDD/F in the rear XAD-2 cartridge demonstrated a reliable trapping efficiency in our sampling system. With a significant amount captured in the front cartridge of XAD-2 resin, MCDF dominates the distribution of PCDD/F. The loading of captafol in the experiment amounted to $15.8 \mathrm{mg}$, which resulted in a PCDD/F yield (w/w) of $30.9 \mu \mathrm{g} \cdot \mathrm{g}^{-1} \mathrm{captafol}$ 
We also detected 15 regulated congeners excluding OCDD/F, with the toxic equivalence (TEQ) of $122 \mathrm{ng} \cdot \mathrm{g}^{-1}$ captafol based on the WHO (2005) toxic equivalency factors, with the detailed quantifications listed in Table 3.

Table 2. Quantification of detected PCDD/F ( $\mu \mathrm{g} \cdot \mathrm{g}^{-1}$ captafol) at $600{ }^{\circ} \mathrm{C}$ under the OXD conditions.

\begin{tabular}{ccccc}
\hline Homologue group & Tubes & XAD-2 $^{\mathbf{F}}$ & XAD-2 $^{\mathbf{B}}$ & Total $^{\text {(n) }}$ \\
\hline MCDF & 4.91 & 5.57 & n.d. & 10.5 \\
DCDF & 9.56 & 0.09 & n.d. & 9.68 \\
TriCDF & 2.41 & n.d. & n.d. & 2.41 \\
TCDF & 2.98 & n.d. & n.d. & 2.98 \\
PeCDF & 0.85 & n.d. & n.d. & 0.85 \\
HxCDF & 0.12 & n.d. & n.d. & 0.12 \\
HpCDF & 0.03 & n.d. & n.d. & 0.03 \\
MCDD & 0.77 & 0.33 & n.d. & 1.10 \\
DCDD & 1.54 & n.d. & n.d. & 1.54 \\
TriCDD & 0.66 & n.d. & n.d. & 0.66 \\
TCDD & 0.61 & n.d. & n.d. & 0.61 \\
PeCDD & 0.33 & n.d. & n.d. & 0.33 \\
HxCDD & 0.10 & n.d. & n.d. & 0.10 \\
HpCDD & 0.04 & n.d. & n.d. & 0.04 \\
\hline
\end{tabular}

n.d. - not detected or below limit of detection; F - Front; B - Back;

MCDD/F, DCDD/F, TriCDD/F, TCDD/F, PeCDD/F, HxCDD/F and HpCDD/F denote mono-, di-, tri-, tetra-, penta-, hexa- and hepta- chlorinated dibenzo-p-dioxins and dibenzofurans

Table 3. Quantifications of regulated PCDD/F congeners at $600{ }^{\circ} \mathrm{C}$ under the OXD conditions.

\begin{tabular}{cccc}
\hline Homologue group & $\begin{array}{c}\text { Emission Factor } \\
\text { (ng.g } \mathbf{~}^{\mathbf{1}} \text { captafol) }\end{array}$ & TEF $^{\mathbf{a}}$ & $\begin{array}{c}\text { TEQ } \\
\text { (ng. }^{-\mathbf{1}} \text { captafol) }\end{array}$ \\
\hline 2,3,7,8-TCDD & 25.7 & 1 & 25.7 \\
2,3,7,8-TCDF & 130 & 0.1 & 13.0 \\
1,2,3,7,8-PeCDD & 38.42 & 1 & 38.4 \\
1,2,3,7,8-PeCDF & 51.65 & 0.03 & 1.55 \\
2,3,4,7,8-PeCDF & 106 & 0.3 & 31.7 \\
1,2,3,4,7,8-HxCDD & 11.3 & 0.1 & 1.13 \\
1,2,3,6,7,8-HxCDD & 11.1 & 0.1 & 1.11 \\
1,2,3,7,8,9-HxCDD & 9.24 & 0.1 & 0.92 \\
1,2,3,4,7,8-HxCDF & 28.4 & 0.1 & 2.84 \\
1,2,3,6,7,8-HxCDF & 16.8 & 0.1 & 1.68 \\
1,2,3,7,8,9-HxCDF & 26.0 & 0.1 & 2.59 \\
2,3,4,6,7,8-HxCDF & 4.84 & 0.1 & 0.48 \\
1,2,3,4,6,7,8-HpCDD & 30.2 & 0.01 & 0.30 \\
1,2,3,4,6,7,8-HpCDF & 30.7 & 0.01 & 0.31 \\
Total & 520 & & 122 \\
\hline
\end{tabular}

${ }^{\mathrm{a}}$ WHO 2005 TEF values [26].

For the sake of comparison, the yield of each product in percentage (\%) mentioned below denotes the mole percent of an initial reactant loading. The results of the decomposition of captan and folpet included hereafter are extracted from our previous studies on these two fungicides [10-12]. The experimental observation of the present research combined with those from our previous investigations on captan and folpet prompt us to make the following comments on the formation pathways of major species from captafol and hence comparison among the sulfenimide fungicides.

Our DFT calculations have revealed that the thermal decompositions of captan and folpet initiate through the fission of $\mathrm{C}-\mathrm{S}$ bond (the weakest bond in their structures), even in the presence of oxygen $[10,13]$. Compared to the trichloromethyl group in captan and folpet, the tetrachloroethyl moiety is expected to 
decrease further the strength of the $\mathrm{C}-\mathrm{S}$ bond in the structure of captafol. The DFT calculations confirmed that the energy required to break the C-S bond of captafol is $4.5 \mathrm{kcal} \cdot \mathrm{mol}^{-1}$ lower than that of folpet or captan. Therefore, the initiation of captafol also proceeds via the rupture of $\mathrm{C}-\mathrm{S}$ bond and the further reactions of the resultant radicals form the observed products, as summarised in Fig. 7

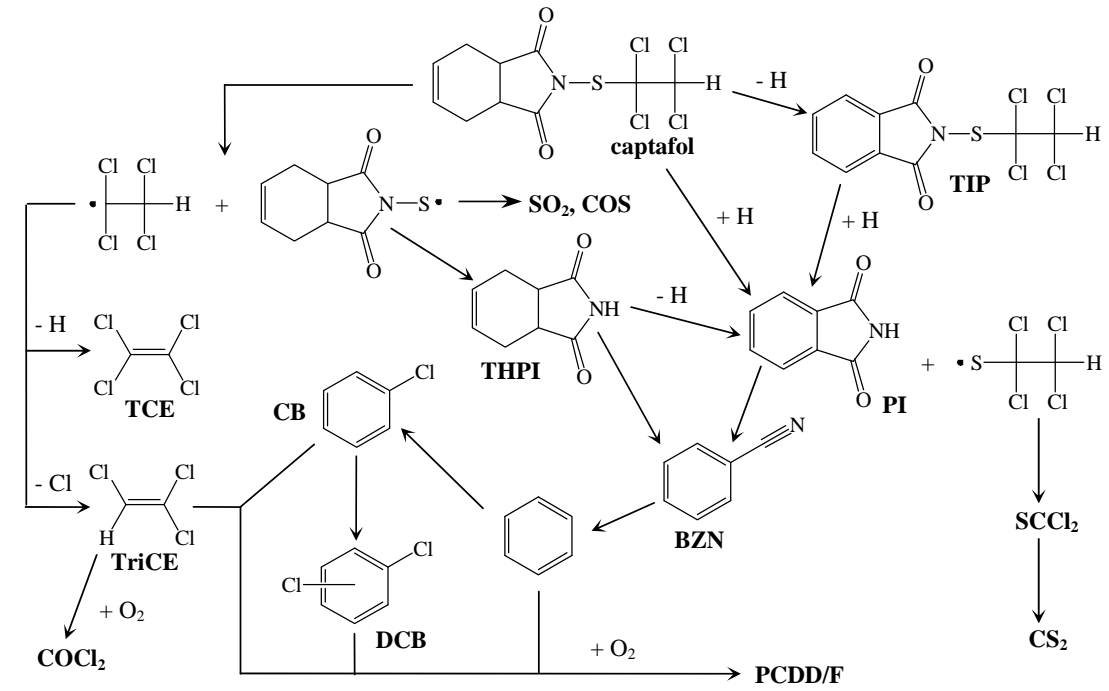

Fig. 7. Pathways to toxicants in the decomposition of captafol.

The thermal decomposition of captan and folpet produced TCE via the self-combination of $\mathrm{CCl}_{3}$ radicals and further loss of $\mathrm{Cl}[10,11]$. In comparison, the formation of small amounts of TCE in the decomposition of captafol originated from the loss of $\mathrm{H}$ from tetrachloroethyl group. The $\mathrm{C}-\mathrm{Cl}$ bond in the tetrachloroethyl group is weaker than the $\mathrm{C}-\mathrm{H}$ bond [27]. Thus, the further reaction of tetrachloroethyl radical should favour the formation of TriCE, as evidenced by the higher yields of TriCE in the VOC measurements. Small amounts of $\mathrm{COCl}_{2}$ were observed in the present study of captafol, but only at $400{ }^{\circ} \mathrm{C}$ in the oxygen rich atmosphere, with the yield (3.5\%) significantly smaller than those from captan and folpet (22.3 and 10.2\%).

The formation pathways from captan or folpet to $\mathrm{COCl}_{2}$ proceed through the fast reaction between $\mathrm{CCl}_{3}$ radical and $\mathrm{O}_{2}[10,11]$. However, the structure of captafol possesses no clear source of $\mathrm{CCl}_{3}$ radical. In addition, the results of captan and folpet point to, even under the LOP conditions in which much less oxygen is present, $\mathrm{O}_{2}$ reacting with $\mathrm{CCl}_{3}$ radical to form $\mathrm{COCl}_{2}[10,11]$. With $\mathrm{COCl}_{2}$ only measured in the OXD experiments, we suspect that captafol produces $\mathrm{COCl}_{2}$ via a different mechanism.

There exist both experimental and theoretical studies on the oxidation of TriCE reporting the formation of $\mathrm{COCl}_{2}$ as an important product [28,29]. These studies provide a reasonable explanation for $\mathrm{COCl}_{2}$ arising from captafol, as a consequence of the oxidation of TriCE. The further oxidation at higher temperatures decreases the formation of $\mathrm{COCl}_{2}$, similarly to the cases of captan and folpet. As the radical pool builds up, the abstraction of $\mathrm{H}$, present on the cyclohexene ring in the structure of captafol, can also take place, leading to free $\mathrm{H}$ radicals and tentatively identified 1,1,2,2-tetrachloroethyl-thiophthalimide (TIP in Fig. 7).

The aromatisation process also converts THPI to PI and these two chemicals can further decompose to BZN, with the detailed mechanisms described elsewhere [13]. Comparable to the results for captan, the oxidation of captafol $\left(22.4 \%\right.$ at $\left.600{ }^{\circ} \mathrm{C}\right)$ leads to higher BZN yields than those of folpet $\left(5.8 \%\right.$ at $\left.600{ }^{\circ} \mathrm{C}\right)$. This indicates that the $\beta$-scission of cyclohexadienyl radical and concurrent loss of $\mathrm{CO}_{2}$ promote the formation of BZN as THPI becomes aromatised. The decomposition of BZN has been documented to produce HCN and benzene [30].

The chlorination of the aromatic compounds serves as a significant source of CB and DCB. The further oxidation of the chlorinated benzenes leads to the formation of PCDD/F through gas phase interactions [31]. The emission of PCDD/F in the oxidation of captan and folpet amounts to $21.5 \mu \mathrm{g} \cdot \mathrm{g}^{-1}$ and $10.7 \mu \mathrm{g} \cdot \mathrm{g}^{-1}$ respectively [11,12], significantly lower than that of captafol $\left(30.8 \mu \mathrm{g} \cdot \mathrm{g}^{-1}\right)$. In addition, penta- to heptachlorinated congeners of PCDD/F are detected only in the experiments with captafol. We also note that 
TriCE forms solely in the oxidation of captafol and the incomplete combustion of TriCE has been reported as a potential pathway for the production of PCDD/F $[32,33]$. Thus, it appears likely that it is the presence of TriCE from the decomposition of captafol that promotes the formation of higher yields of PCDD/F in general, and the appearance of penta to hepta chlorinated PCDD/F, in particular.

Regarding the reactions involving sulfur, the dominant yields of $\mathrm{SO}_{2}$ and $\mathrm{COS}$ point to the oxidation of the active sulfur site, resulting from the fission of the $\mathrm{S}-\mathrm{C}$ bond. The presence of $\mathrm{SCCl}_{2}$ in the OXD experiment of captafol suggests that the $\mathrm{N}-\mathrm{S}$ bond also breaks. In the previous study of captan, we have reported that the addition of $\mathrm{H}$ to the $\mathrm{N}$ of captan facilitates the $\mathrm{N}-\mathrm{S}$ rupture and that the thiotrichloromethyl radical easily converts to $\mathrm{SCCl}_{2}$ via the loss of $\mathrm{Cl}$ [10]. Similarly, we hypothesise that the $\mathrm{N}-\mathrm{S}$ breakage facilitated by $\mathrm{H}$ radicals also occurs in the case of captafol. The resultant thiotetrachloroethyl produces $\mathrm{SCCl}_{2}$ by the expulsion of $\mathrm{CHCl}_{2}$ radical. However, this is a less favourable process compared to the reactions involving thiotrichloromethyl group, as indicated by the lower yield of $\mathrm{SCCl}_{2}$ from captafol (4.6\%) than from captan (11.9\%). Although a pathway leading to significant emission of $\mathrm{CS}_{2}$ in the LOP experiments is somewhat uncertain, further reactions of $\mathrm{SCCl}_{2}$ under the OXD conditions may be attributed to the formation of $\mathrm{CS}_{2}$ via the crucial immediate CS [10].

\section{CONCLUSIONS}

In the present study, we investigated the gas-phase, thermal, non-flame decomposition of captafol under well-controlled conditions. The bench-type experimental apparatus equipped with a sampling train captured a large variety of products, while the analytical techniques used to identify and quantify these products comprised $\mu \mathrm{GC}$, FTIR, GC-QMS and GC-ITMS. Several toxic gaseous, VOC and PCDD/F pollutants were observed, with their emission factors compared under different experimental conditions. These pollutants include phosgene, thiophosgene, trichloroethylene, tetrachloroethylene and 15 regulated toxic PCDD/F congeners; we have detected no OCDD/F. The results of captafol were also compared with those of previous studies on captan and folpet, which indicated the appearance of different pathways due to presence of the thiotrichloromethyl group in captan and folpet, and the thiotetrachloroethyl group in captafol. Only detected in the experiments involving captafol, trichloroethylene promoted higher yields of PCDD/F. A combination of the experimental measurements and DFT calculations enabled us to elucidate the formation pathways to the major toxic species in the thermal decomposition of captafol. The results presented in this contribution also improve the knowledge of fire chemistry of the sulfenimide fungicides and provide quantitative information to assess their potential fire hazards and toxic load of their oxidation products to the surrounding environment.

\section{ACKNOWLEDGEMENT}

This study has been funded by the Australian Research Council. We acknowledge with gratitude discussions with Professors Mohammednoor Altarawneh of Al-Hussein Bin Talal University, Jordan, Adam Grochowalski of the Cracow Technical University, Poland, and Jochen Mueller of The University of Queensland, Australia, as well as with Ms Annabel Mitchell of Varian Australia. KC thanks the University of Newcastle for a postgraduate research scholarship.

\section{REFERENCES}

[1] Zang, X.H., Wang, J.T., Wang, O., Wang, M.Z., Ma, J.J., Xi, G.H., and Wang, Z., (2008) Analysis of Captan, Folpet, and Captafol in Apples by Dispersive Liquid-Liquid Microextraction Combined with Gas Chromatography, Analytical and Bioanalytical Chemistry 392: 749-754, http://dx.doi.org/10.1007/s00216-008-2296-1.

[2] Royal Society of Chemistry, European Directory of Agrochemical Products: Fungicides, Cambridge, 1986, pp. 46-56.

[3] International Agency for Research on Cancer, IARC Monographs on the Evaluation of Carcinogenic Risks of Chemicals to Humans, Lyon, France, 1991, pp. 353-369.

[4] Beckman, T.G., Pusey, P.L., and Bertrand, P.F., (2003) Impact of Fungal Gummosis on Peach Trees, Hortscience 38: 1141-1143. 
[5] Wadikar, M.S., Kadam, V.B., and Kamble, S.S., (2008) Use of Agrochemicals in the Management of Charcoal Rot of Pigeonpea Caused by Macrophomina Phaseolina Resistant to Carbendazim, Plant Archives 8: 159-162.

[6] Nelson, G.L., (2000) Fire and Pesticides, a Review and Analysis of Recent Work, Fire Technology 36: 163-183, http://dx.doi.org/10.1023/A:1015462710856.

[7] Kinsman, P., and Maddison, T.E., (2001) Hazard Assessment for Fires in Agrochemical Warehouses: The Role of Combustion Products, Process Safety and Environmental Protection 79: 145-156, http://dx.doi.org/ 10.1205/09575820150511920.

[8] Karthikeyan, S., Balasubramanian, R., and Iouri, K., (2006) Particulate Air Pollution from Bushfires: Human Exposure and Possible Health Effects, Journal of Toxicology \& Environmental Health Part A: Current Issues 69: 1895-1908, http://dx.doi.org/10.1080/15287390600751264.

[9] Meyer, C.P., Black, R.R., Tolhurst, K.G., McCaw, L., Cook, G., Symons, R., and Mueller, J.F., (2007) Emission of Dioxins from Bush Fires in Australia, Organohalogen Compounds 69: 307310.

[10] Chen, K., Mackie, J.C., Kennedy, E.M., and Dlugogorski, B.Z., (2010) Thermal Decomposition of Captan and Formation Pathways of Toxic Air Pollutants, Environmental Science and Technology 44: 4149-4154, http://dx.doi.org/10.1021/es9037935.

[11] Chen, K., Wojtalewicz, D., Mackie, J.C., Kennedy, E.M., and Dlugogorski, B.Z., "Emission of Toxic Species in Fires of Folpet," Proceedings of 6th International Seminar on Fire and Explosion Hazards, 2010, in press.

[12] Chen, K., Wojtalewicz, D., Altarawneh, M., Mackie, J.C., Kennedy, E.M., and Dlugogorski, B.Z., (2011) Formation of Polychlorinated Dibenzo-P-Dioxins and Dibenzofurans (PCDD/F) in Oxidation of Captan Pesticide, Proceedings of the Combustion Institute 33: 701-708, http://dx.doi.org/10.1016/j.proci.2010.07.069.

[13] Chen, K., Mackie, J.C., Kennedy, E.M., and Dlugogorski, B.Z., (2011) Air Pollutants Formed in Thermal Dcecomposition of Folpet Fungicide under Oxidative Conditions, Environmental Science and Technology 45: 554-560, http://dx.doi.org/10.1021/es102652w.

[14] Klusmeier, W., Ohrbach, K.H., Kühn, P., and Kettrup, A., (1989) Investigations into the Thermal Decomposition of Selected Pesticides, Journal of Analytical and Applied Pyrolysis 16: 205-211, http://dx.doi.org/10.1016/0165-2370(89)80024-5.

[15] International Organization for Standardization, ISO TS 19706, Guidelines for Assessing the Fire Threat to People, 2004.

[16] Bacsik, Z., McGregor, J., and Mink, J., (2007) FTIR Analysis of Gaseous Compounds in the Mainstream Smoke of Regular and Light Cigarettes, Food and Chemical Toxicology 45: 266-271, http://dx.doi.org/10.1016/j.fct.2006.08.018.

[17] Becke, A.D., (1996) Density-Functional Thermochemistry. 4. A New Dynamical Correlation Functional and Implications for Exact-Exchange Mixing, Journal of Chemical Physics 104: 10401046, http://dx.doi.org/10.1063/1.470829.

[18] Chen, H.L., Hai, C.X., Liang, X., Zhang, X.D., Liu, R., and Qin, X.J., (2009) Correlation between sPLA2-IIA and Phosgene-Induced Rat Acute Lung Injury, Inhalation Toxicology 21: 374-380, http://dx.doi.org/10.1080/08958370802449712.

[19] Sharma, S., The Chemistry of Thiophosgene, Harwood Academic Publishers GmbH, Chur, Switzerland, 1986, p. 102.

[20] Singh, B.M., Coles, N., Lewis, P., Braithwaite, R.A., Nattrass, M., and FitzGerald, M.G., (1989) The Metabolic Effects of Fatal Cyanide Poisoning, Postgraduate Medical Journal 65: 923-925, http://dx.doi.org/10.1136/pgmj.65.770.923.

[21] Marcus, W.L., (1992) Health Hazards Resulting from Carbon Disulfide, Journal of Occupational Medicine and Toxicology 1: 159-72. 
[22] Ramanjaneyulu, K., Surendranath, K.N., and Krishnaiah, A., (1989) Excess Volumes of BinaryMixtures of Trichloroethylene with Some Aliphatic, Alicyclic and Aromatic-Hydrocarbons, Fluid Phase Equilibria 44: 357-361, http://dx.doi.org/10.1016/0378-3812(89)80062-7.

[23] Bonacker, D., Stoiber, T., Böhm, K.J., Unger, E., Degen, G.H., Thier, R., and Bolt, H.M., (2004) Chromosomal Genotoxicity of Nitrobenzene and Benzonitrile, Archives of Toxicology 78: 49-57, http://dx.doi.org/10.1007/s00204-003-0508-1.

[24] International Agency for Research on Cancer, Overall evaluation of carcinogenicity: an updating of IARC monographs Volumes 1 to 42. IARC Monographs on the Evaluation of Carcinogenic Risks to Humans, Supplement 7. Lyon, France, 1987. p. 39.

[25] Altarawneh, M., Dlugogorski, B.Z., Kennedy, E.M., and Mackie, J.C., (2009) Mechanisms for Formation, Chlorination, Dechlorination and Destruction of Polychlorinated Dibenzo-p-Dioxins and Dibenzofurans (PCDD/Fs), Progress in Energy and Combustion Science 35: 245-274, http://dx.doi.org/10.1016/j.pecs.2008.12.001.

[26] Van den Berg, M., Birnbaum, L.S., Denison, M., De Vito, M., Farland, W., Feeley, M., Fiedler, H., Hakansson, H., Hanberg, A., Haws, L., Rose, M., Safe, S., Schrenk, D., Tohyama, C., Tritscher, A., Tuomisto, J., Tysklind, M., Walker, N., and Peterson, R.E., (2006) The 2005 World Health Organization Reevaluation of Human and Mammalian Toxic Equivalency Factors for Dioxins and Dioxin-Like Compounds, Toxicological Sciences 93: 223-241, http://dx.doi.org/10.1093/toxsci/kfl055.

[27] Tsang, W., and Walker, J.A., (1995) Hydrogen-Atom-Induced Decomposition of Trichloroethylene at High Temperatures, The Journal of Physical Chemistry 99: 3156-3161, http://dx.doi.org/10.1021/j100010a028.

[28] Itoh, N., Kutsuna, S., and Ibusuki, T., (1994) A Product Study of the OH Radical Initiated Oxidation of Perchloroethylene and Trichloroethylene, Chemosphere 28: 2029-2040, http://dx.doi.org/10.1016/0045-6535(94)90153-8.

[29] Christiansen, C.J., and Francisco, J.S., (2010) Atmospheric Oxidation of Trichloroethylene: An $\mathrm{Ab}$ Initio Study, Journal of Physical Chemistry A 114: 9163-9176, http://dx.doi.org/10.1021/jp103769z.

[30] Etemad-Rad, S.-T., and Metcalfe, E., (1993) The Pyrolysis of Benzonitrile, Fire and Materials 17: 33-37, http://dx.doi.org/10.1002/fam.810170106.

[31] Sommeling, P.M., Mulder, P., and Louw, R., (1994) Formation of PCDFs during Chlorination and Oxidation of Chlorobenzene in Chlorine/Oxygen Mixtures around $340{ }^{\circ} \mathrm{C}$, Chemosphere 29: 20152018, http://dx.doi.org/10.1016/0045-6535(94)90368-9.

[32] Villalobos, S.A., Anderson, M.J., Denison, M.S., Hinton, D.E., Tullis, K., Kennedy, I.M., Jones, A.D., Chang, D.P.Y., Yang, G.S., and Kelly, P., (1996) Dioxinlike Properties of a Trichloroethylene Combustion-Generated Aerosol, Environmental Health Perspectives 104: 734743.

[33] Taylor, P.H., Sidhu, S.S., Rubey, W.A., Dellinger, B., Wehrmeier, A., Lenoir, D., and Schramm, K.W., (1998) Evidence for a Unified Pathway of Dioxin Formation from Aliphatic Hydrocarbons, Symposium (International) on Combustion 27: 1769-1775, http://dx.doi.org/10.1016/S00820784(98)80018-0. 